Bangladesh J. Sci. Res. 30(1\&2): 11-21, 2017 (December)

\title{
EFFECTS OF RICE HULL, RICE STRAW AND SAW DUST APPLICATION ON THE PRIMARY NUTRIENTS OF RICE PLANTS GROWN UNDER VARIABLE MOISTURE CONDITIONS IN A SALINE SOIL
}

\author{
Suma Akter ${ }^{*}$, Md. Harunor Rashid Khan and Mohammed Sadid Hossain \\ Department of Soil, Water and Environment, University of Dhaka, \\ Dhaka 1000, Bangladesh
}

\begin{abstract}
The study was conducted at Kuakata of Patuakhali to evaluate the impacts of indigenous organic amendments such as rice hull, rice straw and saw dust alone and in combination under variable moisture conditions (moist and saturated) on the primary nutrients $(\mathrm{N}, \mathrm{P}$ and K) of BRRI dhan64 grown in a coastal saline soil. The individual application of rice hull, rice straw and saw dust at the rate of 0,4 and $8 \mathrm{t} /$ ha and their combined effects were found to be significant $(\mathrm{p} \leq 0.05)$ for $\mathrm{N}$ content in the rice plants. Effects of the treatments on phosphorus content alone and in combination were slightly additive but not significant. The maximum $\mathrm{P}$ content in the plant tissues was determined at saturated condition with the increased rate of the treatments $\left(\mathrm{T}_{27}=\mathrm{RH}_{8} \mathrm{RS}_{8} \mathrm{SD}_{8}\right)$, while the lowest content of $\mathrm{P}$ was recorded in control $\left(\mathrm{T}_{1}=\mathrm{RH}_{0} \mathrm{RS}_{0} \mathrm{SD}_{0}\right)$. The $\mathrm{K}$ content in plant tissues increased significantly $(\mathrm{p} \leq 0.05)$ with the increased rate of application of rice hull, rice straw and saw dust. The higher $\mathrm{K}$ contents were found under saturated condition of soil. Under moist condition of soil, the highest contents of N, P and K were 21.3, 1.45 and $15.67 \mathrm{~g} / \mathrm{kg}$, respectively and under saturated condition, the highest contents of $\mathrm{N}, \mathrm{P}$ and $\mathrm{K}$ were $23.4,1.78$ and $15.87 \mathrm{~g} / \mathrm{kg}$ by the combined application of rice hull, rice straw and saw dust, respectively at the rate of $8 \mathrm{t} / \mathrm{ha}$, suggested that the primary nutrition of rice had better response under saturated moisture condition in saline soil, which received rice hull, rice straw and saw dust.
\end{abstract}

Key words: Effects, Indigenous, Rice hull, Rice straw, Saw dust, Primary nutrition,

BRRI dhan64

\section{Introduction}

Bangladesh to date depends much on agriculture specially cultivation of rice. Agriculture is a major sector of Bangladesh economy and the coastal area of Bangladesh is suitable for growing rice (SRDI 2010). The coastal areas of Bangladesh constitute about 2.5 million hectares which amount to about 25 per cent of the total crop land of the country (Karim et al. 1990). Of this, nearly 0.84 million hectares are affected by varying intensities of salinity, resulting in very poor land utilization. Salinity is not only the major abiotic stresses limiting profitable crop production but also hamper nutritional balance worldwide (Khan 2016). The problem of salt-affected soils has gained ever-increasing importance in science, technology, ecology, and economics alike during the last decades (Begum and Khan 2013). Soil salinization is closely associated to these often

*Author for correspondence: <suma_nur5@yahoo.com>. 
conflicting requirements and has become a global problem, even one of the most important issues in many countries, as manifested by recent land utilization programs taking into account for the protection of the natural environment (Begum and Khan 2014). Salinization is one of the major soil degradation processes that has turned millions of hectares of our agricultural land unfit for profitable crop production (Khan et al. 2008).

Increased level of salinity negatively influences germination, plant growth and reproducibility, physiological processes, including photosynthesis, respiration, transpiration, membrane properties, nutrient balance, enzymatic activity, and metabolic activities, cellular homeostasis, and hormone regulation and leads to production of Reactive Oxygen Species (ROS); and in severe stress, it leads to plant death (Hasanuzzaman et al. 2012). Salinity is a continuous process and its remediation is cost and labor-intensive. It is a complex global problem that cannot be solved simply; rather multidisciplinary approaches are required. To date, different approaches have been suggested to solve these issues, such as, soil leaching with water, chemical amendment, and phytoremediation (Ahmad and Chang 2002, Sharma and Minhas 2005). Tejada et al. (2006) suggested for the use of organic fertilizers for reclaiming saline and sodic soils, which may increase their fertility but need to be assessed.

There are various ways for remediation and proper utilization of saline soils including agronomic practices, use of salt-tolerant crop varieties, use of indigenous organic amendments and phytoremediation. The present state of knowledge demonstrated that among the different methods and techniques, the use of indigenous organic amendments can be cost effective and environmentally sound technology for remediation of salt impacted sites and also deserve special attention for research and development of coastal salt impacted areas.

Rice straw is an organic material available in significant quantities at the farmers' level. Rice straw contains numerous elements essential for plant growth, including nitrogen, phosphorus, and potassium (Gaihre et al. 2013). Approximately $40 \%$ of N, 30 to $35 \%$ of P, and $80-85 \%$ of $\mathrm{K}$ taken up by rice remain in the straw at crop maturity (Dobermann and Fairhurst 2002). Conrad (2002) reported that rice straw also contains different biopolymers such as cellulose (32 - 37\%), hemicelluloses $(29-37 \%)$, and lignin $(5-15 \%)$. These nutrients are released from these compounds to soil through mineralization processes and are, therefore, available for subsequent crop growth (Byous et al. 2004). In many studies, recycling of rice straw is reported to increase the organic carbon and nutrient contents in soil (Misra et al. 1996, Eagle et al. 2000). Rice hull improved water holding capacity of soil. It also increased organic matter content of the soil and subsequently increased crop yield (Begum and Khan 2013). The application of rice hull and sawdust increased organic matter in the soil which in turn increased nitrogen to the soil and also increased nitrogen content in plant tissues (Kaniz and Khan 2013). Water movement is one of the major problems in saline soils due to the adverse effects of salinity on soil physical properties which may improve by the indigenous organic amendments like rice hull, rice straw and saw dust. Against this background, the present study was undertaken to evaluate the effects of rice hull, rice 
straw, saw dust under variable moisture conditions on the primary nutrients of rice plant grown in a coastal saline soil.

\section{Materials and Methods}

A field study was conducted with a T. Boro rice cultivar (BRRI dhan64) at Musulliabad (Lata Chapli), Kalapara, Patuakhali, Bangladesh during January to June, 2016. The soil used for this experiment was analyzed for several physico-chemical characteristics following standard methods (Table 1). The bulk soil samples were air-dried and crushed to $2 \mathrm{~mm}$ before analysis. After treatment with $1 \mathrm{M} \mathrm{CH}_{3} \mathrm{COONH}_{4}\left(\mathrm{pH} 5.0\right.$ ) and with $30 \% \mathrm{H}_{2} \mathrm{O}_{2}$ to remove free salts and organic matter, respectively particle size distribution of the initial soil was determined by the Hydrometer method (Piper 1966). Soil pH was measured for the air dried soil in soil-water ratio of $1: 2.5$ using a Corning pH meter Model-7 as described by Jackson (1973). The electrical conductivity of soil solution was determined from saturation extract according to USSLS (1954). Organic matter content was determined (Nelson and Sommers 1982) by wet combustion with $\mathrm{K}_{2} \mathrm{Cr}_{2} \mathrm{O}_{7}$. Available $\mathrm{N}\left(1 \mathrm{~N} \mathrm{KCl}\right.$ extraction), (Jackson 1973), available $\mathrm{P}\left(0.5 \mathrm{M} \mathrm{NaHCO}_{3}, \mathrm{pH} 8.5\right.$ extraction, (Olsen et al. 1954) and available $\mathrm{K}\left(1 \mathrm{M} \mathrm{CH}_{3} \mathrm{COONH}_{4}\right.$, $\mathrm{pH} 7.0$ extraction) (Pratt 1965) were determined. Cation exchange capacity was determined by saturation with $1 \mathrm{M} \mathrm{CH}_{3} \mathrm{COONH}_{4}(\mathrm{pH} 7.0)$, ethanol washing, $\mathrm{NH}_{4}{ }^{+}$displacement with acidified $10 \% \mathrm{NaCl}$, and subsequent analysis by steam (Kjeldhal method) distillation (Black 1965). Exchangeable $\mathrm{Na}^{+}, \mathrm{K}^{+}, \mathrm{Ca}^{2+}$ and $\mathrm{Mg}^{2+}$ were extracted with $1 \mathrm{M} \mathrm{CH}_{3} \mathrm{COONH}_{4}(\mathrm{pH} 7.0)$ and determined by flame photometry $\left(\mathrm{Na}^{+}, \mathrm{K}^{+}\right)$(Black 1965) and Atomic Absorption Spectrometry (AAS) (Hesse 1971). For saturation extract of soil, water soluble $\mathrm{SO}_{4}{ }^{2-}$ and $\mathrm{Cl}^{-}$(Jackson 1973), $\mathrm{HCO}_{3}{ }^{-}$and $\mathrm{CO}_{3}{ }^{2-}$ (USSLS 1954) contents were determined.

Indigenous organic amendments, viz. rice hull (RH), rice straw (RS) and saw dust (SD) were used for the reclamation and improvement of crop production and nutritional balance in saline soil. The experiment was conducted following 3 factorial design with the application of RH $\times \mathrm{RS}$ $\times \mathrm{SD}$ at the rate of 0,4 and $8 \mathrm{t} / \mathrm{ha}$ having 3 replications under 2 moisture (moist and saturated) conditions in the field. Basal doses of $\mathrm{N}, \mathrm{P}_{2} \mathrm{O}_{5}$ and $\mathrm{K}_{2} \mathrm{O}$ were applied at the rate of 120,60 and 80 $\mathrm{kg} / \mathrm{ha}$ from urea, TSP and MoP fertilizers, respectively. The whole TSP, MoP and half of the urea were applied during soil preparation by thorough mixing of fertilizers with the soils. The remaining urea was top dressed in two splits, one at active tillering and another at panicle initiation stage of rice.

Seedlings were collected from the local experienced farmers. Thirty-days-old seedlings of BRRI dhan64 were transplanted at the rate of 3 seedlings per hill. The hill to hill and row to row distances were 18 and $22 \mathrm{~cm}$, respectively. For proper establishment of the rice seedlings, all plots in the field were irrigated with pond water for two weeks after transplantation and then the moisture levels were controlled. In the case of moist condition, $80 \%$ water content was maintained, i.e. not allowed standing water. But in the case of saturated condition, more than $100 \%$ water, i.e. $3-5 \mathrm{~cm}$ standing water was maintained throughout the growing period. Intercultural operations were performed as required. 
Plant samples were collected after harvesting the crop at maturity. The plants per plot were cut at the (1 cm above) ground level and total $\mathrm{N}, \mathrm{P}$ and $\mathrm{K}$ in rice straw (Jackson 1973) were determined. The significance of different treatments alone and in combination in relation to the control was determined by Duncan's New Multiple Range Test (DMRT).

Table 1. Physico-chemical properties of initial soil on oven dry basis.

\begin{tabular}{|c|c|}
\hline Properties & Values \\
\hline Particle density $\left(\mathrm{g} \mathrm{cm}^{-3}\right)$ & 2.53 \\
\hline Bulk density $\left(\mathrm{g} \mathrm{cm}^{-3}\right)$ & 1.37 \\
\hline Porosity (\%) & 45.81 \\
\hline Moisture content (\%; Black 1965) & 3.31 \\
\hline Textural class (Hydrometer method; Piper 1966) & Clay loam \\
\hline pH (1 : 2.5; Jackson, 1973) & 6.90 \\
\hline EC (dS m${ }^{-1} ;$ Saturation extract, $1: 5 ;$ USSLS 1954) & 3.96 \\
\hline Organic carbon (g/kg; Nelson and Sommers 1982) & 7.80 \\
\hline Total nitrogen (g/kg; Jackson 1973) & 0.60 \\
\hline Available nitrogen (mg/kg; $1 \mathrm{~N} \mathrm{KCl}$; Jackson 1973) & 54.55 \\
\hline Available phosphorus (mg/kg; Olsen 1954) & 12.58 \\
\hline Available potassium (mg/kg; Pratt 1965) & 25.00 \\
\hline \multicolumn{2}{|l|}{ Exchangeable cations (c mol/kg; $\left.1 \mathrm{~N} \mathrm{CH}_{3} \mathrm{COONH}_{4}\right)$} \\
\hline Sodium (flame photometer) & 3.91 \\
\hline Potassium (flame photometer) & 0.64 \\
\hline Calcium $\left(\mathrm{AAS}^{*}\right)$ & 1.87 \\
\hline Magnesium (AAS*) & 3.26 \\
\hline \multicolumn{2}{|l|}{ Water soluble anions (c mol/kg) } \\
\hline Chloride (0.005 $\mathrm{N} \mathrm{AgNO}_{3}$; USSLS 1954) & 2.87 \\
\hline Sulphate $\left(\mathrm{BaCl}_{2} ;\right.$ USSLS 1954) & 1.45 \\
\hline Bicarbonate $\left(0.05 \mathrm{~N} \mathrm{H}_{2} \mathrm{SO}_{4}\right.$; USSLS 1954) & 0.47 \\
\hline Carbonate $\left(0.05 \mathrm{~N} \mathrm{H}_{2} \mathrm{SO}_{4}\right.$; USSLS 1954) & ND* \\
\hline Cation exchange capacity (c mol/kg; Black 1965) & 18.67 \\
\hline Sodium adsorption ratio (USSLS 1954) & 7.72 \\
\hline Exchangeable sodium percentage (USSLS 1954) & 20.92 \\
\hline
\end{tabular}

ND* $=$ Not in detectable range, $\mathrm{AAS}^{*}=$ Atomic absorption spectrophotometer.

\section{Results and Discussion}

Nitrogen content: The present investigation revealed that the nitrogen contents at maturity stage of rice plants grown in saline soil were influenced by the application of variable indigenous organic amendments (Fig. 1, Table 2). The individual and the combined effects of rice hull, rice straw and saw dust as indigenous organic amendments on total nitrogen content of the rice plant tissues were found to be significant $(\mathrm{p} \leq 0.05$, Table 2$)$. 
The present results demonstrated that the total nitrogen content in rice straw increased with the increased rate of the application of organic amendments and the effects were more pronounced with their combined application (Fig. 1). Both the single and combined application of these organic amendments (RH, RS and SD) were found to be more striking in increasing nitrogen content at the higher moisture level in the soil. The maximum nitrogen content in the rice straw was recorded at $\mathrm{RH}_{8} \mathrm{RS}_{8} \mathrm{SD}_{8}$ treatment under both moisture levels. But the saturated condition has attained better than those of moist condition in increasing nitrogen content in the rice straw, which might be the resultant effect of the addition of organic matter in turn, nitrogen to the soil under saturated soil condition.

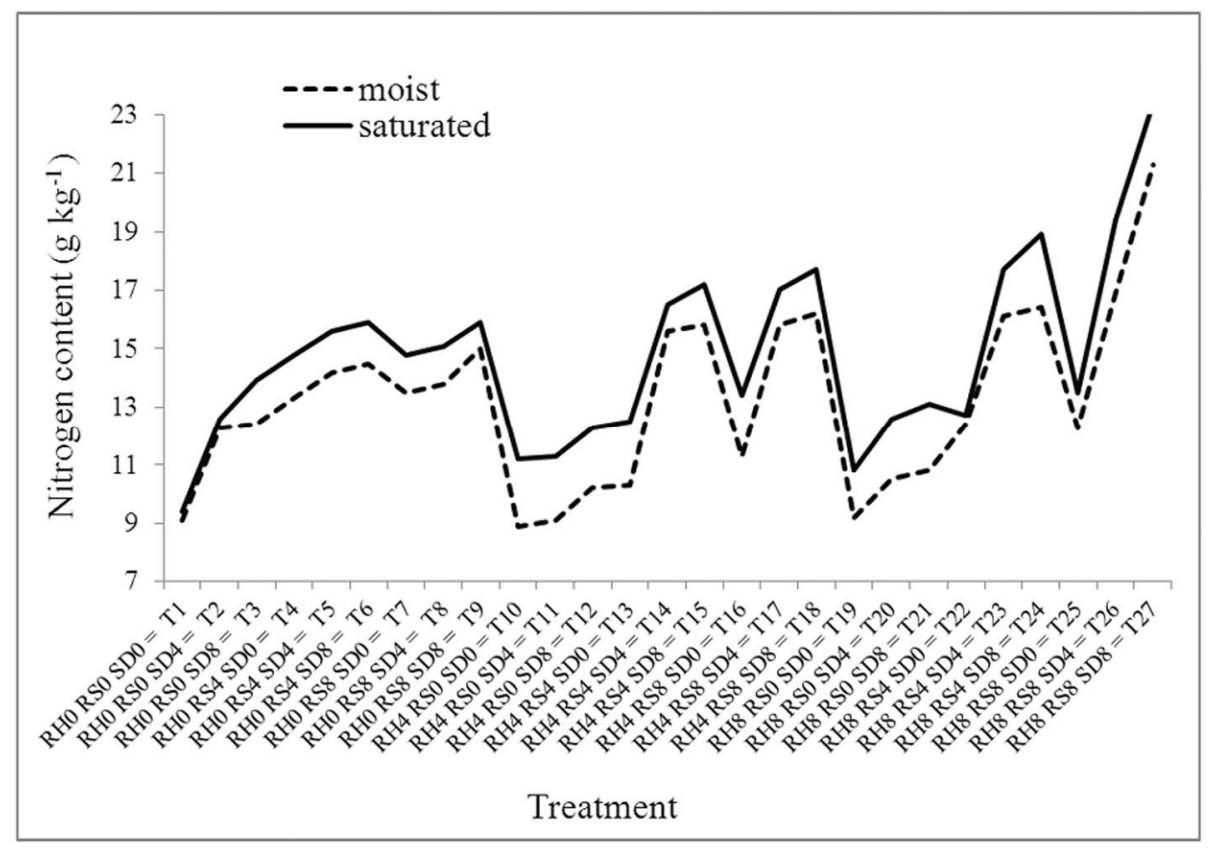

Fig. 1. Nitrogen content in plant tissues of rice (BRRI dhan64) grown under field experiment as influenced by the application of rice hull, rice straw, saw dust and moisture conditions.

Among the three kinds of amendments, regardless of their doses (4, $8 \mathrm{t} / \mathrm{ha})$, rice straw exerted best response (14.71 $\mathrm{g} \mathrm{N} / \mathrm{kg}$ of rice straw) followed by saw dust $(14.27 \mathrm{~g} / \mathrm{kg})$ and rice hull (13.29 $\mathrm{g} / \mathrm{kg}$ ) in increasing nitrogen content of plant tissues at moist condition of the soil (Table 2). These effects of the amendments were more pronounced (rice straw $16.23 \mathrm{~g} \mathrm{~N} / \mathrm{kg}$ of plant tissue, saw dust $15.90 \mathrm{~g} / \mathrm{kg}$ and rice hull $15.07 \mathrm{~g} / \mathrm{kg}$ ) under saturated soil condition (Table 2), which might be due to the increased rate of decomposition and release of nitrogen with time in presence of water saturated condition of the soil. With the elapse period of time, these rate of decomposition and release of nutrients may be changed, which required further study on the residual effects of the amendments. 
Table 2. Comparison of nitrogen content $(\mathrm{g} / \mathrm{kg})$ in rice plants grown under moist and saturated soil conditions as influenced by the application of rice hull (RH), rice straw (RS) and saw dust (SD).

\begin{tabular}{|c|c|c|c|c|c|c|c|}
\hline \multicolumn{8}{|c|}{ Moist condition } \\
\hline \multirow{2}{*}{\multicolumn{2}{|c|}{$\mathrm{RH} \times \mathrm{RS} \times \mathrm{SD}$}} & \multirow{2}{*}{$\begin{array}{l}\text { Rice straw } \\
\text { (RS: t/ha) }\end{array}$} & \multicolumn{3}{|c|}{ Saw dust (SD: t/ha) } & \multirow[t]{2}{*}{ RH- mean } & \multirow[t]{2}{*}{ RS- mean } \\
\hline & & & 0 & 4 & 8 & & \\
\hline \multirow{9}{*}{ 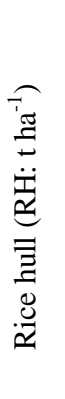 } & \multirow{3}{*}{0} & 0 & $9.1 \mathrm{ab}$ & $12.3 \mathrm{cgl}$ & $12.4 \mathrm{cgh}$ & \multirow{3}{*}{$13.12 \mathrm{a}$} & \multirow{3}{*}{$\begin{array}{l}10.28 \mathrm{~b} \\
(0 \mathrm{t} / \mathrm{ha})\end{array}$} \\
\hline & & 4 & $13.3 \mathrm{chi}$ & 14.2 hijm & $14.5 \mathrm{dijm}$ & & \\
\hline & & 8 & $13.5 \mathrm{chi}$ & $13.8 \mathrm{chim}$ & 15.0deijm & & \\
\hline & \multirow{3}{*}{4} & 0 & $8.9 \mathrm{a}$ & $9.1 \mathrm{ab}$ & $10.2 \mathrm{abk}$ & \multirow{3}{*}{$12.58 \mathrm{~b}$} & \multirow{3}{*}{$\begin{array}{l}14.29 \mathrm{a} \\
(4 \mathrm{t} / \mathrm{ha})\end{array}$} \\
\hline & & 4 & $10.3 \mathrm{abk}$ & 15.6 defjm & 15.8 defi & & \\
\hline & & 8 & $11.3 \mathrm{gkl}$ & 15.8 defi & $16.2 \mathrm{def}$ & & \\
\hline & \multirow{3}{*}{8} & 0 & $9.2 \mathrm{ab}$ & $10.5 \mathrm{abkl}$ & $10.8 \mathrm{bgkl}$ & \multirow{3}{*}{$13.99 \mathrm{a}$} & \multirow{3}{*}{$\begin{array}{l}15.12 \mathrm{a} \\
(8 \mathrm{t} / \mathrm{ha})\end{array}$} \\
\hline & & 4 & $12.4 \mathrm{cgh}$ & $16.1 \mathrm{def}$ & $16.4 \mathrm{ef}$ & & \\
\hline & & 8 & $12.3 \mathrm{cgl}$ & $16.9 \mathrm{f}$ & $21.3 \mathrm{n}$ & & \\
\hline \multirow{2}{*}{\multicolumn{3}{|c|}{ Saw dust (SD)-mean }} & $11.14 \mathrm{c}$ & $13.81 \mathrm{~b}$ & $14.73 \mathrm{a}$ & & \\
\hline & & & \multicolumn{3}{|c|}{ Saturated condition } & & \\
\hline \multirow{9}{*}{ 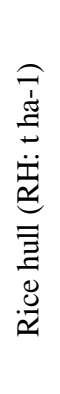 } & \multirow{3}{*}{0} & 0 & $9.4 \mathrm{~m}$ & $12.6 \mathrm{abcd}$ & 13.9 aghi & \multirow{3}{*}{$14.22 \mathrm{~b}$} & \multirow{3}{*}{$\begin{array}{l}11.91 \mathrm{~b} \\
(0 \mathrm{t} / \mathrm{ha})\end{array}$} \\
\hline & & 4 & 14.8 eghi & $15.6 \mathrm{eij}$ & 15.9 efi & & \\
\hline & & 8 & 14.8 eghi & 15.1 ehi & 15.9 efi & & \\
\hline & \multirow{3}{*}{4} & 0 & $11.2 \mathrm{bc}$ & $11.3 \mathrm{bcd}$ & $12.3 \mathrm{abcd}$ & \multirow{3}{*}{$14.34 \mathrm{~b}$} & \multirow{3}{*}{$\begin{array}{l}15.76 \mathrm{a} \\
\text { (4 t/ha) }\end{array}$} \\
\hline & & 4 & $12.5 \mathrm{abcd}$ & 16.5 efi & 17.2 fik & & \\
\hline & & 8 & $13.4 \mathrm{agh}$ & $17.0 \mathrm{fi}$ & $17.7 \mathrm{fkl}$ & & \\
\hline & \multirow{3}{*}{8} & 0 & $10.8 \mathrm{bm}$ & $12.6 \mathrm{abcd}$ & $13.1 \mathrm{adg}$ & \multirow{3}{*}{$15.79 \mathrm{a}$} & \multirow{3}{*}{$\begin{array}{l}16.69 \mathrm{a} \\
(8 \mathrm{t} / \mathrm{ha})\end{array}$} \\
\hline & & 4 & $12.7 \mathrm{acd}$ & $17.7 \mathrm{fkl}$ & $18.9 \mathrm{kl}$ & & \\
\hline & & 8 & $13.5 \mathrm{agh}$ & 19.41 & $23.4 \mathrm{n}$ & & \\
\hline \multicolumn{3}{|c|}{ Saw dust (SD)-mean } & $12.57 \mathrm{~b}$ & $15.31 \mathrm{a}$ & $16.48 \mathrm{a}$ & & \\
\hline
\end{tabular}

In a column and row, means followed by a common letter are not significantly different at $5 \%$ level (by DMRT).

Phosphorus content: Phosphorus contents in rice plants at different moisture levels were found to be influenced by the application of rice hull, rice straw and saw dust (Fig. 2). The results reveal that the effects of the treatments alone and in combination were additive but not statistically significant. The maximum phosphorus content $(1.78 \mathrm{~g} / \mathrm{kg})$ in the rice plant tissues were determined at saturated soil condition with the increased rates of the amendments, which might be attributed to the favorable $\mathrm{pH}$ condition attained by the combined application of these indigenous amendments resulting good nutrition of $\mathrm{P}$ in plants. Though there was no pronounced variation in $\mathrm{P}$ contents in rice plants among the different treatments. The second highest $(1.68 \mathrm{~g} / \mathrm{kg}) \mathrm{P}$ content was noted in $\mathrm{T}_{26}\left(\mathrm{RH}_{8} \mathrm{RS}_{8} \mathrm{SD}_{4}\right)$ followed by $\mathrm{T}_{24}\left(\mathrm{RH}_{8} \mathrm{RS}_{4} \mathrm{SD}_{8}\right)$ treatments. 


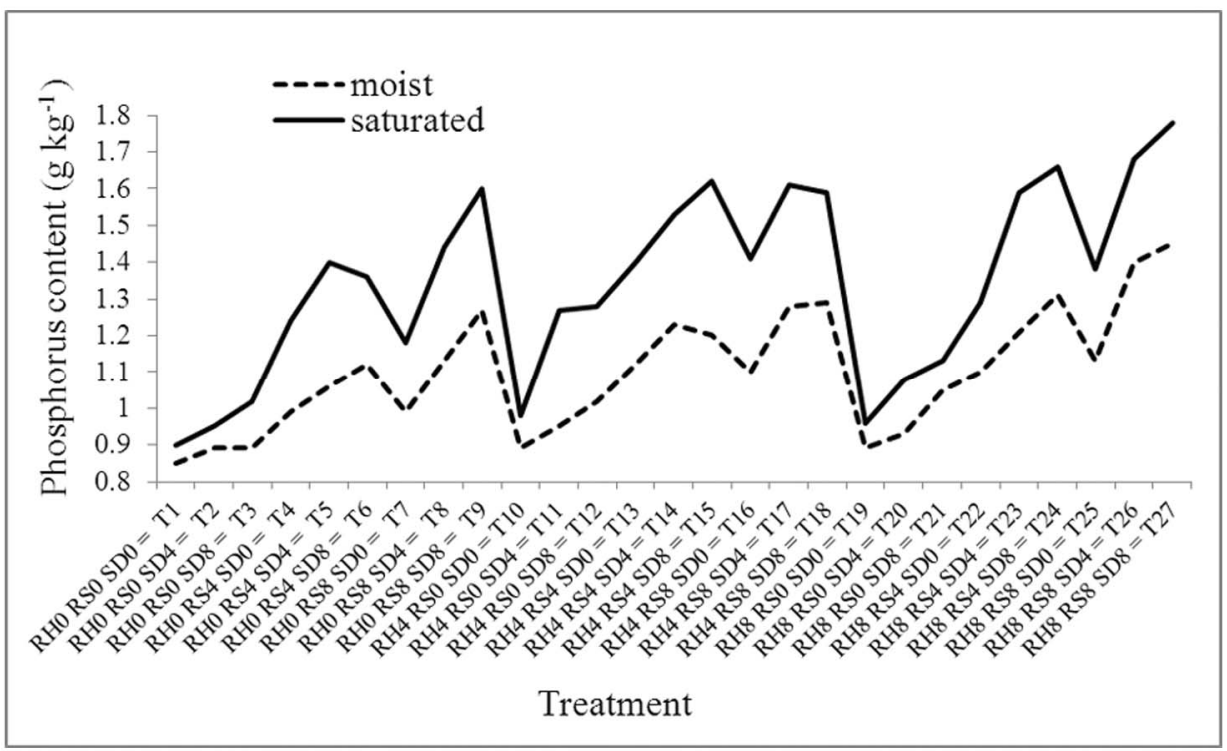

Fig. 2. Phosphorus content in plant tissues of rice (BRRI dhan64) grown under field experiment as influenced by the application of rice hull, rice straw, saw dust and moisture conditions.

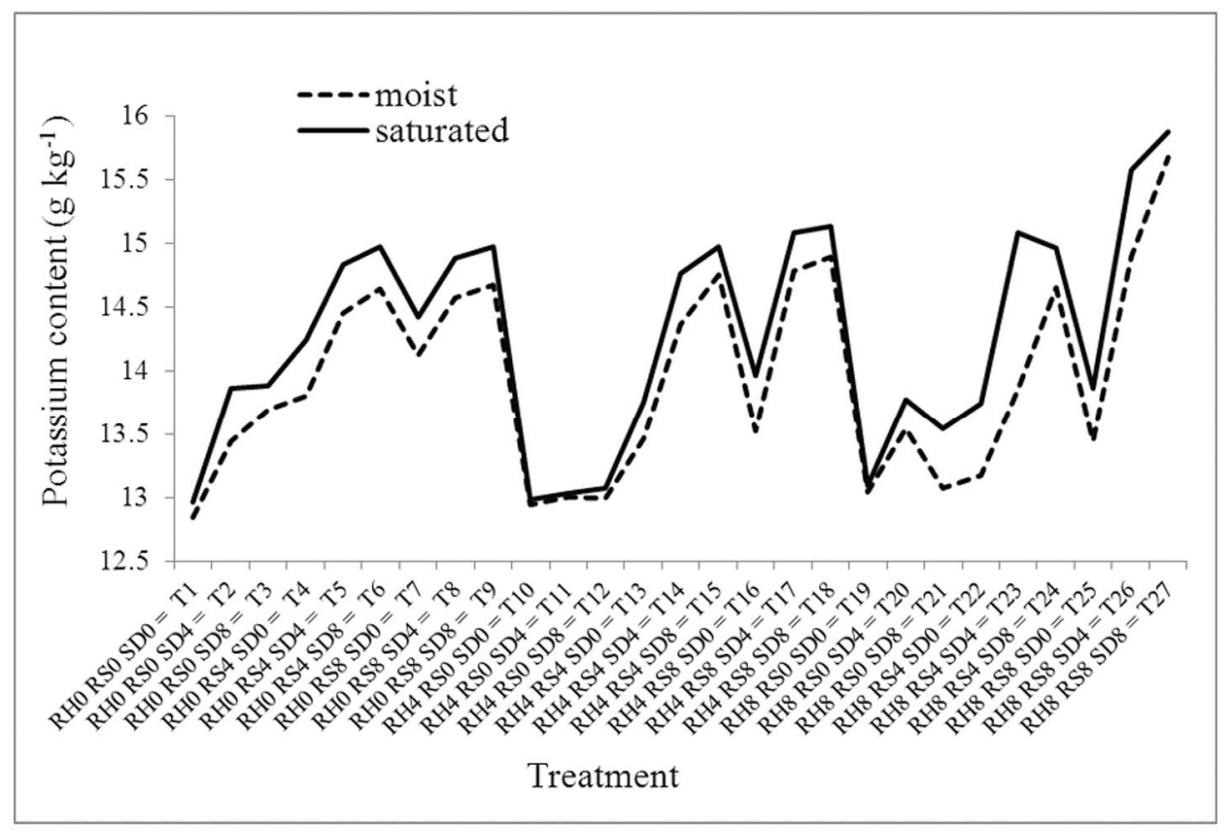

Fig. 3. Potassium content in plant tissues of rice (BRRI dhan64) grown under field experiment as influenced by the application of rice hull, rice straw, saw dust and moisture conditions. 
Potassium content: The potassium content in rice plant tissues increased significantly ( $\mathrm{p} \leq$ 0.05 ) by the application of different rates of rice hull, rice straw and saw dust (Fig. 3, Table 3). The test of significance of different treatment means were compared by DMRT at maturity. The values of $\mathrm{K}$ contents were found to be higher with the combinations of treatments at saturated condition, which was assumed due to the inhibition effect of $\mathrm{K}$ on $\mathrm{Na}$ content in the saline soil. Hence, the present practices of organic amendments seemed to be a good initiative for the production of rice in saline soil as $\mathrm{K}$ is an important structural primary nutrient of plants and also faces problem in uptake under saline condition.

Table 3. Comparison of potassium content $(\mathrm{g} / \mathrm{kg})$ in rice plants grown under moist and saturated conditions as influenced by the application of rice hull (RH), rice straw (RS) and saw dust (SD).

\begin{tabular}{|c|c|c|c|c|c|c|c|}
\hline & & & Mo & st condition & & & \\
\hline $\mathrm{RH}$ & $\times \mathrm{SD}$ & Rice straw & & aw dust (SD: & & RH- & RS- \\
\hline & & (RS: t/ha) & 0 & 4 & 8 & mean & mean \\
\hline & & 0 & $12.85 \mathrm{~b}$ & $13.45 \mathrm{ab}$ & $13.69 \mathrm{ab}$ & & $13.18 \mathrm{~b}$ \\
\hline & 0 & 4 & $13.80 \mathrm{abc}$ & $14.45 \mathrm{abc}$ & $14.64 \mathrm{abc}$ & 14.03 & (0 t/ha) \\
\hline Еี & & 8 & $14.12 \mathrm{abc}$ & $14.57 \mathrm{abc}$ & $14.67 \mathrm{abc}$ & & \\
\hline$\ddot{\ddot{I}}$ & & 0 & $12.95 \mathrm{ab}$ & $13.01 \mathrm{ab}$ & $13.00 \mathrm{ab}$ & & $14.13 \mathrm{a}$ \\
\hline$\stackrel{2}{2}$ & 4 & 4 & $13.47 \mathrm{ab}$ & $14.36 \mathrm{abc}$ & $14.75 \mathrm{abc}$ & 13.86 & \\
\hline$\overline{\bar{z}}$ & & 8 & $13.53 \mathrm{ab}$ & $14.78 \mathrm{abc}$ & $14.89 \mathrm{ac}$ & & \\
\hline .0 & & 0 & $13.05 \mathrm{ab}$ & $13.55 \mathrm{ab}$ & $13.08 \mathrm{ab}$ & & $14.51 \mathrm{a}$ \\
\hline & 8 & 4 & $13.18 \mathrm{ab}$ & $13.85 \mathrm{abc}$ & $14.65 \mathrm{abc}$ & 13.93 & (8t/ha) \\
\hline & & 8 & $13.45 \mathrm{ab}$ & $14.89 \mathrm{ac}$ & $15.67 \mathrm{c}$ & & \\
\hline Saw & $(\mathrm{SD})-\mathrm{r}$ & & 13.38 & 14.10 & 14.33 & & \\
\hline & & & Saturate & condition & & & \\
\hline & & 0 & $12.97 \mathrm{a}$ & $13.86 \mathrm{abcd}$ & $13.88 \mathrm{abcd}$ & 14.34 & $13.36 \mathrm{~b}$ \\
\hline & 0 & 4 & 14.24 abcde & 14.83 abcde & 14.97 abcde & & (0 t/ha) \\
\hline हี & & 8 & 14.42 abcde & 14.88 abcde & 14.97 abcde & & \\
\hline$\stackrel{\vec{I}}{\ddot{I}}$ & & 0 & $12.99 \mathrm{a}$ & $13.04 \mathrm{a}$ & $13.08 \mathrm{ab}$ & 14.08 & $14.59 \mathrm{a}$ \\
\hline$\stackrel{2}{2}$ & 4 & 4 & $13.75 \mathrm{abcd}$ & 14.76 abcde & 14.97 abcde & & \\
\hline $\bar{\Xi}$ & & 8 & 13.96 abcde & 15.08 bcde & $15.13 \mathrm{cde}$ & & \\
\hline.$\tilde{J}$ & & 0 & $13.10 \mathrm{ab}$ & $13.77 \mathrm{abcd}$ & $13.55 \mathrm{abc}$ & 14.39 & $14.86 \mathrm{a}$ \\
\hline & 8 & 4 & $13.74 \mathrm{abcd}$ & 15.08 bcde & 14.96 abcde & & (8t/ha) \\
\hline & & 8 & $13.86 \mathrm{abcd}$ & $15.57 \mathrm{de}$ & $15.87 \mathrm{e}$ & & \\
\hline Saw & $(\mathrm{SD})-\mathrm{r}$ & & 13.67 & 14.54 & 14.60 & & \\
\hline
\end{tabular}

In a column and row, means followed by a common letter are not significantly different at $5 \%$ level (by DMRT).

The increasing order of $\mathrm{K}$ contents in rice straw under different treatments followed the sequence of $\mathrm{T}_{27}\left(\mathrm{RH}_{8} \mathrm{RS}_{8} \mathrm{SD}_{8}\right)>\mathrm{T}_{26}\left(\mathrm{RH}_{8} \mathrm{RS}_{8} \mathrm{SD}_{4}\right)>\mathrm{T}_{24}\left(\mathrm{RH}_{8} \mathrm{RS}_{4} \mathrm{SD}_{8}\right)>\mathrm{T}_{18}\left(\mathrm{RH}_{4} \mathrm{RS}_{8} \mathrm{SD}_{8}\right)>\mathrm{T}_{17}$ $\left(\mathrm{RH}_{4} \mathrm{RS}_{8} \mathrm{SD}_{4}\right)>\mathrm{T}_{15}\left(\mathrm{RH}_{4} \mathrm{RS}_{4} \mathrm{SD}_{8}\right)>\mathrm{T}_{6}\left(\mathrm{RH}_{0} \mathrm{RS}_{4} \mathrm{SD}_{8}\right)$. The present results showed that the combination of rice straw and saw dust were more pronounced as compared to the combination of 
rice hull with those treatments. The interactions of these three treatments were significantly $(\mathrm{p} \leq$ 0.05) synergistic as compared to the control.

Regardless of rates of the treatments, rice hull, rice straw and saw dust (mean values of RH, RS, SD; Tables 2 and 3) exerted almost similar effects on N, P and $\mathrm{K}$ contents in BRRI dhan64 plants tissues, which might be due to inherent organic carbon status of amendments. These carbon contents of the amendments are very important for the productivity and fertility of soil and these are also proved by the present influences of these organic amendments on the primary nutrients in the studied rice plants. However, under moist condition rice hull (according to mean value) did not behave as the trend of increment shown by rice straw and saw dust on $\mathrm{N}$ and $\mathrm{K}$ contents in rice plant. But under saturated condition the effects of these organic amendments on the increment of $\mathrm{N}$ and $\mathrm{K}$ contents in rice plants were more striking, which suggest that soil water is an important factor for the management of the organic amendments for the effective nutritional balance in saline soil.

\section{Conclusion}

The present experimental findings suggest that the application of these kinds of organic amendments, viz. rice hull, rice straw and saw dust were found to be increased nitrogen, phosphorus and potassium nutrition of rice cultivated under saline soil. Among the three kinds of amendments, regardless of their dosages $(4,8 \mathrm{t} / \mathrm{ha})$, rice straw exerted best response followed by saw dust and rice hull in increasing nitrogen content of rice plants grown at moist condition of the soil. These effects of the amendments were more pronounced under saturated soil condition. The maximum phosphorus content in the rice plant tissues were determined at saturated condition of the soil with the increased rate of treatments. The combination of the higher dosage $(8 \mathrm{t} / \mathrm{ha})$ of rice hull, rice straw and saw dust at saturated condition attained the best performance among the treatments, which reveals that the interactions of these organic amendments are effectively synergistic in order to boost up the rice production under saturated saline soil environment. However, further research is needed.

\section{Acknowledgements}

The study was carried out under the project entitled 'Multidisciplinary Approaches for Green Transformation and Development of Agriculture in Salt-affected Coastal Soils under Changing Climatic Conditions' funded by the Ministry of Science and Technology (Ref. 2015-2016/BS-109, dated 08.12.2015). The authors are also grateful to the Ministry of Science and Technology for providing NST fellowships for the first (SA) and Third (MSH) authors of this research paper.

\section{References}

Ahmad, R. and M.H. Chang. 2002. Salinity control and environmental protection through halophytes. J. Drain. Water Manag. 6: 17-25. 
Begum, M. and H.R. Khan. 2013. Influence of gypsum, rice-hull and different levels of saline water irrigation on water soluble cations and organic matter content in different saline soils in response to wheat. International J. Res. Applied Nat. and Social Sci. 1: 15-22.

Begum, M. and H.R. Khan. 2014. Physico-chemical characteristics of saline soil under wheat as influenced by gupsum, rice hull and different salinity levels. International J. Res. Applied Nat. and Social Sci. 298: 121-126.

Black, C.A. (ed.). 1965. Methods of soil analysis, Part 2, Series 9, pp. 894-1372, Am Soc. Agron. Inst. Publ., Madison, WI.

Byous, E.W., J.E. Williams, G.E. Jonesa, W.R. Horwath and C. Kessel. 2004. Nutrient requirements of rice with alternative straw management. Better Crops 36: 6-11.

Conrad, R. 2002. Control of microbial methane production in wetland rice fields. Nut. Cyc. Agro. 64: 59-69.

Dobermann, A. and T.H. Fairhurst. 2002. Rice Straw Management. In: Taken from Better Crops International, Special supplement publication: Rice Production, vol. 16. Published by the Potash and Phosphate Institute of Canada.

Eagle, A.J., J.A. Bird, W.R. Horwaath, B.A. Linquist, S.M. Brouder, J.E. Hill and C.V. Kessel. 2000. Rice yield and nitrogen utilization efficiency under alternative straw management practices. Agron. J. 92: 1096-1103.

Gaihre, Y.K., R. Wassmann and G. Villegas-Pangga. 2013. Impact of elevated temperatures on greenhouse gas emissions in rice systems: Interaction with straw incorporation studied in a growth chamber experiment. Plant Soil 373: 857-875.

Hasanuzzaman, M., M.A. Hossain, J.A. Teixeira de Silva and M. Fujita. 2012. Plant responses and tolerance to abiotic oxidative stress: Antioxidant defense is a key factor in crop stress and its management: perspectives and strategies, V. Bandi, A.K. Shanker, C. Shanker and M. Mandapaka, Springer, Berlin, Germany, Eds. 261-316.

Hesse, P.R. 1971. A Text Book of Soil Chemical Analysis, John Murry Publ., London: 106-234.

Jackson, M.L. 1973. Soil Chemical Analysis, Prentice Hall of India Pvt. Ltd., New Delhi. 36-196.

Kaniz, F. and H.R. Khan. 2013. Reclamation of saline soil using gypsum, rice hull and saw dust in relation to rice production. J. Adv. Sci. Res. 4(3): 1-5.

Karim, Z., S.G. Hussain and M. Ahmed. 1990. Salinity problems and crop intensification in the coastal regions of Bangladesh. Soils Publication No. 33, BARC, 63.

Khan, H.R. 2016. Nutrition of rice as influenced by reclamation techniques for acid sulfate soil in Cox's Bazar. Bangladesh J. Sci. Ind. Res. 52(2): 135-144.

Khan, H.R., S.M. Kabir, M.M.A. Bhuiyan, H.-P. Blume, Y. Oki and T. Adachi. 2008. Reclamation of a Badarkhali hot spot of acid sulfate soil in relation to rice production by basic slag and aggregate treatments under modified-plain-ridge-ditch techniques. Soil Science and Plant Nutrition 54(4): 574586.

Misra, R.D., V.K. Gupta and D.S. Pandey. 1996. Management crop residues in rice. Int. Rice Res. Notes 21: 71-72.

Nelson, D.W. and L.E. Sommers. 1982. Total carbon, organic carbon and organic matter. In: Methods of Soil Analysis, part 2. Agron. Series 9. Page A.L. (ed.). pp. 539-579, Am. Soc. Agron., Publ. Madison, WI, USA.

Olsen, S.R., C.V. Cale, F.S. Watanabe, and L.A. Dean. 1954. Estimation of available phosphorus in soils by extraction with sodium bicarbonate. USDA Circ. 939, Washington, USA. 
Piper, C.S. 1966. Soil and Plant Analysis. Hano Publ. Bombay, India.

Pratt P.F. 1965. Methods of Soil Analysis (Black C.A. Ed.) pp. 1022. Am. Soc. Agron. Madison, Wisconsin, USA.

Sharma, B.R. and P.S. Minhas. 2005. Strategies for managing saline/alkali waters for sustainable agricultural production in South Asia. Agric. Water Manag. 78: 136-151.

SRDI. 2010. Saline soils of Bangladesh. SRMAF project. Ministry of Agriculture, Govt. of Bangladesh, Farmgate, Dhaka.

Tejada, M., C. Garcia, J.L. Gonzalez and M.T. Hernandez. 2006. Use of organic amendment as a strategy for saline soil remediation: Influence on the physical, chemical and biological properties of soil. Soil Biol. Biochem. 38: 1413-1421.

USSLS (United States Salinity Laboratory Staff). 1954. Diagnosis and improvement of saline and alkali soils. In: USDA Handbook No. 60. pp. 84-156. US Govt. Print. Office, Washington, USA.

(Manuscript received on 13 July, 2017; revised on 21 November, 2017) 